\title{
PIK3R3 Gene
}

National Cancer Institute

\section{Source}

National Cancer Institute. PIK3R3 Gene. NCI Thesaurus. Code C24674.

This gene plays a role in cell cycle regulation and hormonal signaling. 